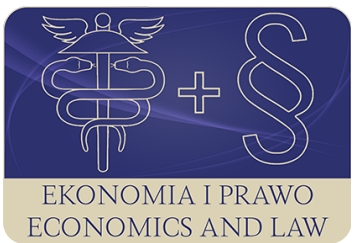

EKONOMIA I PRAWO. ECONOMICS AND LAW

Volume 19, Issue 2, June 2020

p-ISSN 1898-2255, e-ISSN 2392-1625

www.economicsandlaw.pl

EKONOMIA I PRAWO
ECONOMICS AND LAW

ORIGINAL ARTICLE

received 30.03.2019; revised 12.12.2019; accepted 30.06.2020

Citation: Kotliński, K. (2020). Contributions to inflation after euro adoption: the case of Central and Eastern European countries. Ekonomia i Prawo. Economics and Law, 19(2): 305-318.

doi:10.12775/EiP.2020.021.

\title{
Contributions to inflation after euro adoption: the case of Central and Eastern European countries
}

\author{
KAMIL KOTLIŃSKI \\ University of Warmia and Mazury in Olsztyn, Faculty of Economics, Department of Theory \\ of Economics, ul. R. Prawocheńskiego 19, 10-720 Olsztyn, Poland \\ 曰k.kotlinski@uwm.edu.pl \\ (D) orcid.org/0000-0002-5754-8363
}

\begin{abstract}
Motivation: Based on theory, the introduction of a single currency should cause a decrease in transaction costs, which in effect should lead to a drop in consumer prices. However, there is a common perception that the introduction of the single currency is conductive to excessive price increases with this providing a sufficient justification against the introduction of the euro. People subjectively estimate information on a certain economic phenomenon, and that estimation may not necessarily correspond to facts. The discrepancy between perceived inflation and its actual level in the new euro area member states may result from different inflation levels among varying consumption categories.

Aim: The aim of the presented research is to assess the impact of the introduction of the single currency (euro) on the inflation rate in a breakdown by COICOP category in 5 countries of Central and Eastern Europe, which in the years 2007-2015 adopted the common EU currency.

Results: The research was carried out using the comparative method. The inflation indicators were used in 12 categories of classification of individual consumption by purpose (COICOP). The research was conducted using a medium-term perspective: from the five years before the adoption of the euro to five years after its implementation. After the adoption of the euro, prices grew faster than the general indicator of inflation in two COICOP categories. The first of them was restaurants and hotels; while the second was alcoholic beverages, tobacco and narcotics. In the case of other inflation categories, no regularity was observed. In all investigated Central and Eastern European countries, the medium-term HICP inflation was lower after euro adoption than before.
\end{abstract}


Keywords: euro area; new member states; inflation; euro adoption JEL: B31; F31; F45

\section{Introduction}

The first round of the euro cash changeover took place on 1 January 2002 and involved the following 12 countries: Austria, Belgium, Finland, France, Germany, Greece, Ireland, Italy, Luxembourg, the Netherlands, Portugal and Spain. Cyprus and Malta joined on 1 January 2008. The cash changeover triggered a heated discussion about its effect on inflation in literally all countries of the euro area. There is a general belief in the public that the changeover has increased prices dramatically.

Among the 10 EU Member States that geographically belong to Central and Eastern Europe - half have joined the Euro. Slovenia joined the Eurozone on 1 January 2007, Slovakia on 1 January 2009, Estonia on 1 January 2011, Latvia on 1 January 2014 and Lithuania on 1 January 2015. Public opinion and some researchers have feared (Hałka \& Leszczyńska-Paczesna, 2019, pp. 226-241; Hüfner \& Koske, 2008, p. 5) that adopting the euro as a new currency would also give rise to more medium-term effects on prices, notably for countries with a lower income level than the euro area average; like Central and Eastern European EU-members. The countries of Central and Eastern Europe are similar to Poland in terms of the level of economic development and the time since introducing a market economy. The above mentioned countries became members of the European Union at the same time. Therefore, there is some possibility that the changes that have occurred in these countries after the introduction of the single currency may also be revealed in other Central and Eastern European countries, who have not adopted the single euro currency yet.

The reduction of transaction costs is one of the advantages of a common currency (Mongelli, 2008, pp. 1-57; Nguyen \& Rondeau, 2019, pp. 729-743). The elimination of currency exchange uncertainty is considered to be another direct advantage of a common currency (Svrtinov et al., 2014, pp. 57-64). The reduction of transaction costs and uncertainty decreases price volatility (Startiene et al., 2019, pp. 201-215), so inflation should not increase. As a result of the conversion of the national currency into the euro, there was no increase in the money supply in circulation and the purchasing power of the society did not grow. The change of the national currency into the euro was nominal, and thus it did not trigger any significant economic stimulants of short-term price growth in this way. Therefore, there are no rational premises that could, based on economic considerations, explain the possible process of immediate price growth as a consequence of the adoption of the euro's common currency (Folkertsma et al., 2002, p. 9; Heller et al., 2019). The impact of the changeover on the aggregate price level was negligible, but at a lower level of aggregation an effect on prices was noticeable. Prices in some sectors increased significantly in some countries; however, there were also countries where the im- 
pact appeared to be absent. People perceived the euro changeover as having had a profound impact on prices. This phenomenon is sometimes considered to be something policy makers cannot do much about. Eife (2006, pp. 1-30) argue that, this is actually caused by the inexperience of the authorities to cope with such a phenomenon. As with the actual impact, the perceived impact can be avoided with good economic policy. Countries joining in later may use the experience of other countries and, thanks to the appropriate policy, avoid the unfavourable phenomena associated with the adoption of the euro.

The discrepancy between perceived inflation and its actual level in the new euro area member states may also result from the experience of countries in which - as a result of the price rounding effects - there was an increase in the prices of some consumer goods. The aim of the presented research is to assess the impact of the introduction of the single currency (euro) on the inflation rate in a breakdown by COICOP category (Eurostat (2019) data was chosen) in 5 countries of Central and Eastern Europe, which in the years 2007-2015 adopted the common EU currency. In other words, the purpose is to indicate which categories of consumer goods and services are characterized as having the highest price increase after the euro changeover.

The main method used in this study was comparative analysis. The inflation level of each class ECOICOP was compared to the total inflation index in the five countries studied (Slovenia, Slovakia, Estonia, Latvia and Lithuania) over the medium term, i.e. 5 years before and 5 years after the adoption of the euro.

The structure of this paper is as follows. The second section reviews the empirical literature on discrepancy between perceived inflation and its actual level with a special focus on the Central and Eastern European countries. The third section describes the methodology of the research. The fourth section contains a presentation of the results. The last section contains a discussion and a comparison of the findings of other authors, and then a conclusion is presented along with a direction for further research.

\section{Literature review}

A number of factors explaining changeover-related inflation have been put forward by the existing literature. First, the introduction of a new currency is costly and firms need to raise prices to compensate for this (Gaiotti \& Lippi, 2008, pp. 71-107; Hobijn et al., 2006, pp. 1103-1131). Costs include menu costs that arise from the replacement of price labels, and information technology costs. As the direct costs apply for a limited period of time, it follows that they should lead to only temporary increases in prices (Merikull \& Room, 2015, pp. 822-839).

The literature related to this topic mostly focuses on the various reasons why inflation accelerates, since it is mostly believed that firms will try to take advantage of the currency changeover to raise prices. However, with the euro adoption it is also possible that elevated public concern about changeover-re- 
lated inflation may have lead to the opposite effect and induced firms to skip price increases (Eife, 2006, pp. 1-30). Folkertsma et al. (2002, pp. 7-11) point out that upward pressure on prices can also be caused by rounding to 'attractive prices'. This effect should be symmetric since firms should be equally likely to round prices up or down. However, rational firms that are minimizing costs in the longer term round prices up rather than down, within reasonable limits (Aucremanne \& Cornille, 2001, pp. 1-35; Folkertsma et al., 2002, pp. 1-21).

Although the conversion had mild effects on overall inflation in the countries that introduced the euro, the majority of their citizens felt that the adoption of the euro triggered a significant increase in prices. This is evident from the considerable increase in the gap between the perceived inflation level by consumers and the actual inflation measured by the official consumer price index in the period after conversion (Pufnik, 2017, p. 1).

Pufnik (2017, pp. 1-11) states that the most important factors that might influence increases in perceived inflation following the conversion of the domestic currency to the euro are: changes in the prices of frequently bought products, asymmetric influence of price increases or decreases, reduced transparency of prices, expectations regarding price movements after the conversion, the quantity of news about inflation in the media and a comparison of current prices with outdated prices in the national currency.

Adopting the euro as a new currency may also give rise to more medium-term effects on prices economies that are catching-up. As the price level in countries with a lower income level typically converges to the higher price levels of more advanced economies, their real exchange rates tend to appreciate. In the past, the real appreciation was to a large extent reflected in an appreciation of the nominal exchange rate. However, with the euro adoption, this channel was no longer available and the catch-up process showed up as higher inflation rates (Degler \& Staehr, 2019; Hüfner \& Koske, 2008, p. 5; Pietrucha, 2015, pp. 39-40).

On the other hand, inflation in new EU-members degreased in the medium-term. Many studies (Borgersen \& King, 2011, pp. 26-53; Gil-Alana et al., 2017, pp. 45-56; Hegerty, 2018, pp. 1-21; Koukouritakis, 2017, pp. 239-258; Merikull \& Room, 2015, pp. 822-839) have found some evidence of a convergence in inflation and other macro-economic variables between new Euro members and the rest of the euro area.

Dziuda \& Mastrobuoni (2009, pp. 101-129) have proposed a model in which consumers are rational but have difficulty dealing with prices after a cash changeover. A new currency decreases the transparency of prices, thus hindering price comparisons. This weakens competition between retailers: differences in price levels are not perfectly observable, which generates incentives to increase prices. As a result, the equilibrium price is higher after the changeover, even in competitive markets. As the costs borne by consumers due to incorrect price recalculations are small for low-priced products, it is assumed that the incentive to raise prices is inversely proportional to the price level. Therefore, 
the model the authors developed shows that after the euro changeover a higher price growth was experienced by relatively cheaper goods, which had a stronger effect on inflation perceptions.

\section{Methods}

The main method used in this study was comparative analysis. The examined countries adopted the euro in different years (Slovenia - 2007, Slovakia 2009, Estonia - 2011, Latvia - 2014 and Lithuania - 2015). Research during identical calendar years has not been possible. Each of the five countries surveyed adopted a common currency in a different period. The research covered the five years before the adoption of the euro and the five years after its implementation. In this way, a comparable phase of adoption of the euro by particular countries was achieved, while at the same time differing price factors could have affected the price growth, which could shape inflation differently depending on the year under study.

A hypothesis: The adoption of the euro had no impact on total consumer price indices, but it is possible to identify the inflation components in which prices did rise in all countries of Central and Eastern Europe that joined the euro area. The discrepancy between perceived inflation and its actual level in the new euro area member states may result from higher inflations levels in some consumption categories.

The data source used was the European Statistical Office Eurostat (2019). The Harmonised Index of Consumer Prices (HICP) gives comparable measures of inflation for the countries and country groups for which it is produced. It is an economic indicator that measures the change over time of the prices of consumer goods and services acquired by households. In other words, it is a set of consumer price indices (CPI) calculated according to a harmonised approach and a set of definitions as laid down in regulations and recommendations. In addition, the HICP provides the official measure of consumer price inflation in the euro area for the purposes of monetary policy and the assessment of inflation convergence as required under the Maastricht criteria for accession to the euro. The HICP components are currently classified according to the ECOICOP (European Classification of individual consumption by purpose). The Classification of individual consumption by purpose, abbreviated as COICOP, is a classification developed by the United Nations Statistics Division to classify and analyse individual consumption expenditures incurred by households, non-profit institutions serving households and the general government according to their purpose. The main ECOICOP headings are:

- all-items (total or all-items index);

- food and non-alcoholic beverages;

- alcoholic beverages and tobacco;

- clothing and footwear;

- housing, water, electricity, gas and other fuels; 
- furnishings, household equipment and routine maintenance of the house;

- health;

- transport;

- communication;

- recreation and culture;

- education;

- restaurants and hotels;

- miscellaneous goods and services.

All these categories have been examined. The unit used was an annual average rate of change.

The European Central Bank has defined price stability as a year-on-year increase in the Harmonised Index of Consumer Prices (HICP) for the euro area of below $2 \%$. If, therefore, after the introduction of the common currency inflation is close to the inflation target, it means that the common monetary policy has had positive effects, and the excessive rise in prices is only an illusion. If the price level of a category has increased more than the general index, it could have affected the public perception that the changeover has led to general price increases. The method of investigation is not particularly complicated, but the tested group of countries is very small. The emphasis is on the comparative aspect.

\section{Results}

Slovenia was the first post-transition country to adopt the euro. In the first and second year after the changeover, the inflation rate was higher than the inflation target of the European Central Bank (table 1). In the third year (2009) the inflation rate dropped to $0.8 \%$, in subsequent years it has stabilized at a level slightly above the inflation target. Sectors with significant prices increases were: food and non-alcoholic beverages (3.7 percentage points above the general price increase rate in 2007 and 4.1 p.p. in 2008), restaurants and hotels (3.5 p.p. above the all-items HICP index in 2007, 3.7 p.p. in 2008 and 3.9 p.p. above the all-items HICP index in 2009), alcoholic beverages, tobacco and narcotics (3 p.p. above the all-items HICP index). In the first two categories, there was a continuous increase over the five years before the euro changeover. However, the food and non-alcoholic beverages category was characterized by inflation below the overall rate throughout the entire period considered before the adoption of the euro. Before the adoption of the Euro, the average HICP inflation rate over 5 years was $4.3 \%$, and the average inflation rate for the 5 years after the adoption of the euro was $2.9 \%$.

Slovakia adopted the euro in 2009, which means that the first period with the common currency coincided with the financial crisis. Although the overall inflation rate exceeded the ECB's inflation target (except for 2007), it was exceptionally low for the first two years after the adoption of the euro (see table 2). After the euro cash changeover prices of food, clothing, foot wear, fur- 
nishings, household equipment, routine house-hold maintenance and transport decreased. However, there was an increase in the inflation rate of alcoholic beverages, tobacco and narcotics from $4.4 \%$ to $8.7 \%$. The inflation rates in the categories of education and health were significantly higher than the overall index for almost all of the investigated period. In the first two years after euro adoption, higher inflation rates characterized the restaurants and hotel category, as well as miscellaneous goods and services. In the medium term, they reached a level close to the general inflation rate. The overall average HICP inflation rate over 5 years before the adoption of the euro was $4.1 \%$, and the average rate over 5 years after the adoption of the euro was 2.2\%.

The Estonian government took a number of initiatives to ensure price transparency after the changeover and to minimize the inflationary effects. There were no changes in the value-added tax (VAT) rates and alcohol excise taxes, but the excise tax on tobacco was increased in January 2011 (Merikull \& Room, 2015 , p. 825). In the first year general inflation rate increased from $2.7 \%$ to $5.1 \%$. Although only two years before the changeover it was low, previously Estonia was struggling with inflation significantly exceeding the inflation target of the ECB (see table 3). In the short term, inflation rates higher than the overall average were noticed in the following categories: food and non-alcoholic beverages; alcoholic beverages, tobacco and narcotics; housing, water, electricity, gas and other fuels; transport; restaurants and hotels. In Estonia there was a fast steady increase in the prices of housing, water, electricity, gas and other fuels in the medium term before euro adoption (see table 3 ). In the medium term inflation rates higher than the general indicator were in the following categories: restaurants and hotels; alcoholic beverages, tobacco and narcotics; clothing and foot wear. However, the medium-term average all-item HICP inflation rate dropped from $4.9 \%$ (average over 5 years before euro changeover) to $2.6 \%$ (average over 5 years after euro adoption).

In Latvia, for 3 years after joining the euro area, the HICP inflation rate was very low; lower than $1 \%$ (see table 4 ). In the first year after the changeover, the highest inflation rate was noticed in the categories of restaurants and hotels (3.9\%); alcoholic beverages, tobacco and narcotics (2.3\%); as well as miscellaneous goods and services (1.8\%). These categories were characterized by higher inflation than the general index in the medium term as well. In the case of Latvia, a short-term drop prices was observed for the categories: food and non-alcoholic beverages, transport, and communications. In the medium term, there were decreased prices for clothing and foot wear; furnishings, household equipment and routine household maintenance. The average HICP inflation rate over 5 years before the adoption of the euro HICP inflation rate was $1.7 \%$, and the average HICP inflation rate over the 5 years after the adoption of the euro fell to $1.3 \%$.

Lithuania joined the euro area in 2015. Therefore, in contrast to the other countries surveyed, only four years of using the single currency were examined. In the first year of using the common currency in Lithuania, deflation was re- 
corded. The all-items HICP prices index was decreased by $0.7 \%$. A relatively high level of inflation concerned the following categories: restaurants and hotels; alcoholic beverages, tobacco and narcotics; miscellaneous goods and services; as well as education in the short and medium term (see table 5). It should be added that in these categories the medium-term inflation ratios were higher than the general inflation rate in the medium term before the euro changeover, too. The categories of clothing and footwear; furnishings, household equipment and routine household maintenance; health; recreation and culture were characterized by a higher rate of inflation than the general indicator in the first and second year, but were lower in the third and fourth year after the adoption of the euro. The average HICP inflation rate over the 5 years before the euro changeover was $2.0 \%$, and the average HICP inflation rate over the 4 years after euro adoption fell to $1.6 \%$.

The results suggest that changeover-related price increases did indeed occur in similar sectors. In all of the investigated countries, the price growth concentrated in the following categories: restaurants and hotels; alcoholic beverages, tobacco and narcotics.

\section{Conclusion}

The results achieved for the countries of Central and Eastern Europe are similar to those observed in the countries that were the first to adopt the euro. Several contributions (Ehrmann, 2011, pp. 33-58; Ercolani \& Dutta, 2007; Folkertsma et al., 2002; Santos et al., 2002, pp. 101-114) point out that there have been noticeable price increases in some sectors, particularly the service sector, where restaurants, cinemas, dry cleaning and hairdressers have been found to exhibit unusual price increases. Gaiotti \& Lippi (2008, pp. 71-107) found in a panel of 2,500 Italian restaurants that the rise in the price of a restaurant meal compared to 2002 is mainly due to a larger fraction of restaurants revising their prices than to a larger size of the individual price increases. In contrast, Parsley \& Wei (2008, pp. 260-276), compared the prices of a Big Mac Meal, but could not detect any evidence for euro effects.

Pufnik (2017, pp. 7-8) estimated the effects of future euro conversion on the growth of prices of individual components of the harmonized index of consumer prices in Croatia. The largest contribution to the overall conversion induced increases in prices that could come from accommodation and catering services (as regards HICP), as well as recreational and cultural services (with regards to CPI). The phenomenon of prices increasing for faster services can have origins in Balassa-Samuelson effect. Unit labour costs are increase at a relatively faster pace in those euro area economies that started with a significantly lower level of GDP per capita. This effect occurs during the process of catching-up to higher living standards, and might thus be justified to the extent that it reflects convergence towards a new equilibrium (Lenarcic, 2019, pp. 275-305; Mongelli, 2008, pp. 31-32). The Balassa-Samuelson effect is observed not only 
in new Euro members, but also in non-euro economies (Junicke, 2019, pp. 1649-1663; Konopczak \& Welfe, 2017, pp. 1019-1034).

The explanation for the faster growth in prices of some goods and services may be the law of one price, which implies that in a fully competitive market, the prices of the same goods expressed in the same currency should be equal. The convergence is faster in the case of countries with price level below the average, which can be interpreted as catching-up. The existent price level gap between countries poses a risk of higher inflation in some new member states (Hałka \& Leszczyńska-Paczesna, 2019, pp. 226-241).

There is a general belief in the public that the changeover has increased prices dramatically, whereas the statistical evidence does not support this notion. The all-items inflation growth after the euro changeover is a myth. The prices increased above the inflation target in two countries (Slovenia and Estonia), while in three countries HICP inflation was below the target (Slovakia, Latvia, and Lithuania). However, prices in some did sectors increase significantly in Central and Eastern European countries. This research has identified two class of inflation components, which have risen rapidly after euro adoption in all examined Central and Eastern European countries. These were restaurants and hotels; alcoholic beverages, as well as tobacco and narcotics. In the case of other inflation categories, no regularity was observed. This paper finds that the reason for a mismatch between the public perception and actual inflation could be a relative faster price rise in these sectors. Public opinion is based on the prices of only a few goods. In all of the investigated Central and Eastern European countries, the medium-term HICP inflation was lower after euro adoption than before. The hypothesis has been confirmed.

This research was based on only twelve main HICP components. In-depth studies should be based on more detailed data. Data for a more detailed level of the ECOICOP are available for most EU Member States. The fear of excessive price increases is a widely accepted argument against the adoption of the single currency. This is also true for Poland and other Central and Eastern Europe countries. If the basis for this fear is only on the discrepancy between perceived inflation and actual inflation, then the causes of this phenomenon should be further investigated and actions should be taken to minimize or completely eliminate it.

\section{References}

Aucremanne, L., \& Cornille, D. (2001). Attractive prices and euro-rounding effects on inflation. National Bank of Belgium Working Paper, 17. doi:10.2139/ ssrn. 1703472.

Borgersen, T.A., \& King, R.M. (2011). Inflation in Latvia: how real is it? Eastern European Economics, 49(3). doi:10.2753/EEE0012-8775490302. 
Degler, M., \& Staehr, K. (2019). Price and income convergence and the dynamic Penn effect in Central and Eastern Europe. Economic Change and Restructuring. Advance online publication. doi:10.1007/s10644-019-09248-6.

Dziuda, W., \& Mastrobuoni, G. (2009). The euro changeover and its effects on price transparency and inflation. Journal of Money, Credit and Banking, 4l(1). doi:10.1111/j.1538-4616.2008.00189.x.

Ehrmann, M. (2011). Inflation developments and perceptions after the euro cash changeover. German Economic Review, 12(1). doi:10.1111/j.1468-0475.2010.00503.x.

Eife, T. (2006). Price setting behaviour and price setting regulations at the euro changeover. Bank of Estonia Working Papers, 6.

Ercolani, M.G., \& Dutta, J. (2007). The impact of the euro changeover on inflation: evidence from the harmonised index of consumer prices. In: D. Cobham (Ed.), The travails of the eurozone: economic policies, economic developments. Basingstoke: Palgrave. doi:10.1057/9780230801479_10.

Eurostat. (2019). Retrieved 09.12.2019 from https://ec.europa.eu.

Folkertsma, C.K., van Renselaar, C., \& Stokman, A. (2002). Smooth euro changeover, higher prices? Results of a survey among Dutch retailers. Research Memorandum WO, 682.

Gaiotti, E., \& Lippi, F. (2008). Pricing behaviour and the introduction of the euro: evidence from a panel of restaurants. In P. Del Giovane, \& R. Sabbatini (Eds.), The euro, inflation and consumer's perceptions: lessons from Italy. Berlin: Springer. doi:10.1007/978-3-540-78370-1_4.

Gil-Alana, L.A., Mervar, A., \& Payne, J.E. (2017). The stationarity of inflation in Croatia: anti-inflation stabilization program and the change in persistence. Economic Change and Restructuring, 50(1). doi:10.1007/s10644-016-9181-2.

Hałka, A., \& Leszczyńska-Paczesna, A. (2019). Price convergence in the European Union: what has changed? Economic Modelling, 79. doi:10.1016/j. econmod.2018.11.002.

Hegerty, S.W. (2018). Structural breaks and regional inflation convergence for five new Euro members. Economic Change and Restructuring. Advance online publication. doi:10.1007/s10644-018-9241-x.

Heller, J., Warżała, R., \& Kotliński, K. (2019). Introduction of the single currency and inflation: the case of Central and Eastern European countries. Olsztyn Economic Journal, 14(1). doi:10.31648/oej.3966.

Hobijn, B., Ravenna, F., \& Tambalotti, A. (2006). Menu costs at work: restaurant prices and the introduction of the euro. Quarterly Journal of Economics. 121(3). doi:10.1162/qjec.121.3.1103.

Hüfner, F., \& Koske, I. (2008). The euro changeover in the Slovak Republic: implications for inflation and interest rates. OECD Economics Department Working Papers, 632. doi.10.1787/240631807010.

Junicke, M. (2019). Trend inflation and monetary policy in Eastern Europe. Macroeconomic Dynamics, 23(4). doi:10.1017/S1365100517000372. 
Konopczak, K., \& Welfe, A. (2017). Convergence-driven inflation and the channels of its absorption. Journal of Policy Modeling, 39(6). doi:10.1016/j.jpolmod.2017.02.001.

Koukouritakis, M. (2017). Eurozone debt crisis and bond yields convergence: evidence from the new EU countries. Economic Change and Restructuring, 50(3). doi:10.1007/s10644-017-9208-3.

Lenarcic, C. (2019). Inflation: the Harrod-Balassa-Samuelson effect in a DSGE model setting. Economic and Business Review, 21(2). doi:10.15458/ebr.86.

Merikull, J., \& Room, T. (2015). One currency, one price? Euro changeover-related inflation in Estonia. Journal of Common Market Studies, 53(4). doi:10.1111/jcms.12228.

Mongelli, F.P. (2008). European economic and monetary integration, and the optimum currency area theory. European Economy Economic Papers, 302. doi:10.2765/3306.

Nguyen, H.S., \& Rondeau, F. (2019). The transmission of business cycles: lessons from the 2004 enlargement of the EU and the adoption of the euro. Economics of Transition and Institutional Change, 27(3). doi:10.1111/ecot.12212.

Parsley, D., \& Wei, S.-J. (2008). In search of a euro effect: big lessons from a Big Mac meal? Journal of International Money and Finance, 27(2). doi:10.1016/j. jimonfin.2007.12.008.

Pietrucha, J. (2015). Exchange rate regime and external adjustment in CEE countries. Journal of Economics and Management, 20(2).

Pufnik, A. (2017). Effects of the adoption of the euro on consumer prices and inflation perceptions: an overview of experiences and assessment of the possible impact in Croatia. Croatian National Bank Surveys, S-27.

Santos, D., Evagelista, R., Nascimento, T., \& Coimbra, C. (2002). Analysis of the impact of the conversion of escudos into euros. Banco de Portugal Economic Bulletin, 8.

Startiene, G., Dumciuviene, D., Stundziene, A., \& Januskevicius, A. (2019). An impact on the international trade of new EMU members: the Lithuanian case. Entrepreneurial Business and Economics Review, 7(1). doi:10.15678/ EBER.2019.070111.

Svrtinov, V.G., Trajkovska, O.G., \& Temjanovski, R. (2014). Cost and benefits of adopting euro. Applied Sciences and Business Economics Journal, 1(3).

\section{Acknowledgements}

Author contributions: author has given an approval to the final version of the article.

Funding: this research was fully funded by the University of Warmia and Mazury in Olsztyn, Faculty of Economics, Department of Macroeconomics statutory sources.

Note: the results of this study were presented at 10th International Conference on Applied Economics Contemporary Issues in Economy (June 27-28, 2019, Torun, Poland). 


\section{Appendix}

Table 1.

Slovenia inflation: annual average rate of change (in \%)

\begin{tabular}{|c|c|c|c|c|c|c|c|c|c|c|}
\hline \multirow{2}{*}{ Specification } & \multicolumn{5}{|c|}{ Year before euro adoption } & \multicolumn{5}{|c|}{ Year after euro adoption } \\
\hline & 5 th & 4 th & 3rd & 2nd & lst & lst & 2nd & $3 r d$ & 4 th & 5 th \\
\hline all-items HICP & 7.5 & 5.6 & 3.7 & 2.4 & 2.5 & 3.8 & 5.5 & 0.8 & 2.1 & 2.1 \\
\hline food and non-alcoholic beverages & 7.5 & 4.3 & 0.2 & -1.2 & 2.3 & 7.5 & 9.6 & 0.4 & 0.7 & 4.3 \\
\hline $\begin{array}{l}\text { alcoholic beverages, tobacco } \\
\text { and narcotics }\end{array}$ & 13.5 & 11.8 & 5.2 & 4.1 & 4.0 & 6.8 & 3.1 & 6.5 & 7.8 & 5.9 \\
\hline clothing and foot wear & 3.1 & 6.3 & 1.6 & -1.0 & -0.5 & 1.6 & 3.9 & -1.0 & -2.7 & -2.0 \\
\hline $\begin{array}{l}\text { housing, water, electricity, gas } \\
\text { and other fuels }\end{array}$ & 5.6 & 5.7 & 6.7 & 9.2 & 5.4 & 3.5 & 10.0 & -2.4 & 11.8 & 7.0 \\
\hline $\begin{array}{l}\text { furnishings, household } \\
\text { equipment and routine } \\
\text { household maintenance }\end{array}$ & 5.9 & 4.8 & 2.5 & 3.5 & 3.6 & 4.0 & 5.6 & 3.4 & 0.9 & 1.9 \\
\hline health & 6.7 & 5.8 & 1.5 & -0.3 & -1.7 & 1.7 & 3.5 & 4.9 & 1.3 & 1.5 \\
\hline transport & 7.3 & 4.5 & 5.7 & 2.9 & 1.6 & 0.4 & 2.0 & -3.3 & 1.8 & 2.1 \\
\hline communications & 14.9 & 1.1 & -0.1 & -0.2 & 0.4 & 0.6 & -0.1 & -4.1 & 1.3 & 1.2 \\
\hline recreation and culture & 7.9 & 5.2 & 3.5 & 1.2 & 1.3 & 2.9 & 3.6 & 2.6 & 0.3 & -1.5 \\
\hline education & 9.5 & 4.8 & 6.7 & 5.4 & 2.3 & 2.1 & 5.0 & 3.3 & 1.3 & 1.3 \\
\hline restaurants and hotels & 9.0 & 8.6 & 6.1 & 4.6 & 4.4 & 7.3 & 9.2 & 4.7 & -0.5 & -2.7 \\
\hline miscellaneous goods and services & 8.3 & 6.5 & 4.8 & 2.4 & 4.4 & 3.9 & 4.1 & 3.8 & 1.8 & 2.1 \\
\hline
\end{tabular}

Source: Eurostat (2019).

Table 2.

Slovakia inflation: annual average rate of change (in \%)

\begin{tabular}{|c|c|c|c|c|c|c|c|c|c|c|}
\hline \multirow{2}{*}{ Specification } & \multicolumn{5}{|c|}{ Year before euro adoption } & \multicolumn{5}{|c|}{ Year after euro adoption } \\
\hline & 5 th & 4 th & 3rd & 2nd & lst & lst & 2nd & 3rd & 4 th & 5 th \\
\hline all-items HICP & 7.5 & 2.8 & 4.3 & 1.9 & 3.9 & 0.9 & 0.7 & 4.1 & 3.7 & 1.5 \\
\hline food and non-alcoholic beverages & 4.9 & -0.7 & 2.0 & 4.0 & 7.0 & -3.8 & 1.7 & 5.9 & 4.3 & 3.5 \\
\hline $\begin{array}{l}\text { alcoholic beverages, tobacco } \\
\text { and narcotics }\end{array}$ & 8.4 & -0.7 & 3.1 & 4.4 & 4.4 & 8.7 & 6.3 & 3.7 & 3.9 & 3.0 \\
\hline clothing and foot wear & 0.5 & -0.8 & -0.1 & 0.8 & 0.9 & -0.9 & -1.3 & 1.6 & 1.9 & 1.0 \\
\hline $\begin{array}{l}\text { housing, water, electricity, gas } \\
\text { and other fuels }\end{array}$ & 15.9 & 8.2 & 12.1 & 2.3 & 4.2 & 3.4 & -1.4 & 7.0 & 4.8 & 0.2 \\
\hline $\begin{array}{l}\text { furnishings, household } \\
\text { equipment and routine } \\
\text { household maintenance }\end{array}$ & -2.2 & -3.2 & -0.5 & 0.1 & 0.3 & -1.8 & -3.4 & -1.0 & 0.5 & 0.1 \\
\hline health & 13.4 & 8.8 & 9.7 & 0.1 & 8.1 & 8.1 & 4.1 & 4.0 & 5.3 & 2.1 \\
\hline transport & 7.7 & 1.3 & 0.6 & -2.0 & 3.2 & -5.4 & -0.2 & 6.8 & 6.4 & -0.9 \\
\hline communications & 0.4 & -1.1 & -1.1 & -0.3 & -0.8 & 0.2 & 0.8 & 0.4 & 0.2 & 0.2 \\
\hline recreation and culture & 5.4 & 1.8 & 1.7 & 0.9 & 1.2 & -0.2 & 0.7 & 0.4 & 1.6 & 1.7 \\
\hline education & 11.4 & 30.1 & 5.9 & 3.7 & 3.1 & 5.4 & 4.5 & 5.0 & 5.9 & 6.5 \\
\hline restaurants and hotels & 10.3 & 5.3 & 2.6 & 3.0 & 5.9 & 5.0 & 1.3 & 2.5 & 3.4 & 2.4 \\
\hline miscellaneous goods and services & 4.7 & 3.0 & 3.8 & 2.5 & 3.0 & 2.6 & 1.8 & 3.8 & 4.0 & 1.4 \\
\hline
\end{tabular}

Source: Eurostat (2019). 
Table 3.

Estonia inflation: annual average rate of change (in \%)

\begin{tabular}{|c|c|c|c|c|c|c|c|c|c|c|}
\hline \multirow{2}{*}{ Specification } & \multicolumn{5}{|c|}{ Year before euro adoption } & \multicolumn{5}{|c|}{ Year after euro adoption } \\
\hline & 5 th & 4 th & 3rd & 2nd & lst & lst & 2 nd & $3 r d$ & 4 th & 5 th \\
\hline all-items HICP & 4.4 & 6.7 & 10.6 & 0.2 & 2.7 & 5.1 & 4.2 & 3.2 & 0.5 & 0.1 \\
\hline food and non-alcoholic beverages & 4.8 & 9.4 & 14.0 & -3.7 & 2.9 & 9.4 & 3.4 & 4.1 & 0.0 & -0.3 \\
\hline $\begin{array}{l}\text { alcoholic beverages, tobacco } \\
\text { and narcotics }\end{array}$ & 3.5 & 4.1 & 16.0 & 10.7 & 4.6 & 6.3 & 5.4 & 5.2 & 4.2 & 5.1 \\
\hline clothing and foot wear & 3.5 & 4.1 & 4.2 & 1.5 & 2.9 & 4.2 & 5.6 & 4.4 & 1.7 & 2.8 \\
\hline $\begin{array}{l}\text { housing, water, electricity, gas } \\
\text { and other fuels }\end{array}$ & 10.5 & 15.0 & 16.6 & 1.5 & 3.0 & 6.0 & 9.1 & 8.9 & -1.3 & -1.4 \\
\hline $\begin{array}{l}\text { furnishings, household } \\
\text { equipment and routine } \\
\text { household maintenance }\end{array}$ & 2.3 & 3.8 & 4.5 & 2.7 & -0.9 & 0.8 & 2.7 & 1.1 & 1.0 & 1.3 \\
\hline health & 2.7 & 8.3 & 7.8 & 4.3 & 0.8 & 0.6 & -0.5 & 6.3 & 3.5 & 3.2 \\
\hline transport & 4.8 & 3.1 & 11.9 & -6.5 & 6.5 & 5.2 & 4.0 & -2.5 & -2.1 & -6.2 \\
\hline communications & -5.3 & -1.2 & -0.9 & -0.2 & 3.8 & -4.1 & -6.9 & -9.6 & -5.0 & 1.2 \\
\hline recreation and culture & 4.6 & 3.8 & 3.3 & 0.4 & -0.3 & 1.2 & 1.3 & 2.3 & 2.3 & 2.3 \\
\hline education & 3.9 & 5.8 & 8.9 & 4.9 & 1.5 & 2.1 & 5.9 & -3.1 & -16.0 & -16.6 \\
\hline restaurants and hotels & 3.2 & 8.6 & 11.5 & -1.4 & -0.9 & 5.5 & 6.6 & 6.3 & 4.5 & 1.7 \\
\hline miscellaneous goods and services & 4.1 & 5.4 & 8.8 & 7.0 & 1.7 & 3.2 & 2.9 & 2.1 & 2.4 & 2.7 \\
\hline
\end{tabular}

Source: Eurostat (2019).

Table 4.

Latvia inflation: annual average rate of change (in \%)

\begin{tabular}{|c|c|c|c|c|c|c|c|c|c|c|}
\hline \multirow{2}{*}{ Specification } & \multicolumn{5}{|c|}{ Year before euro adoption } & \multicolumn{5}{|c|}{ Year after euro adoption } \\
\hline & 5 th & 4 th & $3 r d$ & 2nd & lst & lst & 2nd & $3 \mathrm{rd}$ & 4 th & 5 th \\
\hline all-items HICP & 3.3 & -1.2 & 4.2 & 2.3 & 0.0 & 0.7 & 0.2 & 0.1 & 2.9 & 2.6 \\
\hline food and non-alcoholic beverages & -0.1 & -0.3 & 8.4 & 2.3 & 1.3 & -0.3 & -1.2 & 1.1 & 5.6 & 0.7 \\
\hline $\begin{array}{l}\text { alcoholic beverages, tobacco } \\
\text { and narcotics }\end{array}$ & 19.7 & 3.0 & 3.4 & 2.9 & 1.6 & 2.3 & 1.8 & 3.3 & 1.4 & 4.3 \\
\hline clothing and foot wear & -5.3 & -5.9 & 1.9 & -1.8 & -0.2 & 1.1 & -0.4 & 0.0 & -1.7 & 0.6 \\
\hline $\begin{array}{l}\text { housing, water, electricity, gas } \\
\text { and other fuels }\end{array}$ & 8.3 & -2.3 & 7.5 & 6.8 & -0.1 & 1.0 & 3.5 & -2.9 & 2.0 & 4.0 \\
\hline $\begin{array}{l}\text { furnishings, household } \\
\text { equipment and routine } \\
\text { household maintenance }\end{array}$ & 0.6 & -5.0 & -1.1 & -0.9 & -0.3 & 1.2 & 1.0 & -0.2 & -0.5 & -0.4 \\
\hline health & 17.9 & 0.1 & -2.6 & 0.4 & 1.2 & 1.0 & 1.5 & 2.6 & 2.8 & 3.4 \\
\hline transport & -2.8 & 4.0 & 7.0 & 2.9 & -2.4 & -1.1 & -3.8 & -2.6 & 3.0 & 4.5 \\
\hline communications & -1.2 & -4.8 & -2.0 & -2.8 & -5.7 & -1.8 & 0.8 & 2.1 & 4.4 & 1.4 \\
\hline recreation and culture & 4.4 & -4.9 & -2.0 & 0.2 & -0.3 & 1.9 & 0.8 & 1.4 & 1.8 & 0.8 \\
\hline education & 18.0 & 5.2 & 0.2 & -1.5 & -0.7 & 0.6 & 1.5 & 1.7 & 1.6 & 0.6 \\
\hline restaurants and hotels & -1.4 & -5.9 & 1.8 & 3.2 & 1.1 & 3.9 & 1.6 & 0.7 & 2.1 & 3.2 \\
\hline miscellaneous goods and services & 4.7 & -3.8 & 0.6 & 1.3 & 1.8 & 1.8 & 1.4 & 0.8 & 5.5 & 5.3 \\
\hline
\end{tabular}

Source: Eurostat (2019). 
Table 5.

Lithuania inflation: annual average rate of change (in \%)

\begin{tabular}{|c|c|c|c|c|c|c|c|c|c|}
\hline \multirow{2}{*}{ Specification } & \multicolumn{5}{|c|}{ Year before euro adoption } & \multicolumn{4}{|c|}{ Year after euro adoption } \\
\hline & 5th & 4th & 3rd & 2nd & lst & lst & 2nd & 3rd & 4th \\
\hline all-items HICP & 1.2 & 4.1 & 3.2 & 1.2 & 0.2 & -0.7 & 0.7 & 3.7 & 2.5 \\
\hline food and non-alcoholic beverages & -0.4 & 8.2 & 3.1 & 1.7 & 0.8 & -0.7 & 1.3 & 3.4 & 1.5 \\
\hline $\begin{array}{l}\text { alcoholic beverages, tobacco } \\
\text { and narcotics }\end{array}$ & 11.3 & 1.0 & 3.6 & 2.9 & 3.8 & 1.7 & 3.7 & 10.7 & 4.0 \\
\hline clothing and foot wear & -5.8 & -1.2 & 0.9 & 1.0 & -0.3 & 0.6 & 1.4 & 0.7 & 0.1 \\
\hline $\begin{array}{l}\text { housing, water, electricity, gas } \\
\text { and other fuels }\end{array}$ & 4.7 & 8.3 & 6.2 & 0.5 & -0.6 & -3.5 & -1.6 & 1.4 & 3.2 \\
\hline $\begin{array}{l}\text { furnishings, household } \\
\text { equipment and routine } \\
\text { household maintenance }\end{array}$ & -2.9 & -0.2 & 1.5 & 1.2 & 0.3 & 1.4 & 1.1 & 1.1 & 0.7 \\
\hline health & 1.2 & 0.8 & 2.1 & 1.8 & 1.2 & 2.7 & 2.8 & 1.0 & 1.4 \\
\hline transport & 5.4 & 8.0 & 4.4 & -0.5 & -1.9 & -7.2 & -3.8 & 5.0 & 4.6 \\
\hline communications & -5.0 & -3.1 & -2.0 & -4.6 & -6.3 & 0.0 & -3.9 & -0.6 & -1.3 \\
\hline recreation and culture & -2.2 & -1.3 & 1.2 & 1.4 & 0.5 & 2.0 & 1.6 & 2.4 & 2.2 \\
\hline education & 7.7 & 0.5 & 3.1 & 3.6 & 1.1 & 2.2 & 3.6 & 2.4 & 3.1 \\
\hline restaurants and hotels & -2.8 & 2.0 & 3.4 & 2.8 & 2.8 & 4.8 & 5.1 & 7.2 & 5.2 \\
\hline miscellaneous goods and services & 0.2 & 1.5 & 3.3 & 1.5 & 0.5 & 2.5 & 3.0 & 5.5 & 3.1 \\
\hline
\end{tabular}

Source: Eurostat (2019). 